\title{
HYPERBARIC OXYGEN THERAPY (HBOT) IN PEDIATRICS
}

\author{
LECZENIE TLENEM HIPERBARYCZNYM (HBOT) W PEDIATRII
}

\section{ЛЕЧЕНИЕ МЕТОДОМ ГИПЕРБАРИЧЕСКОЙ ОКСИГЕНАЦИИ (НВОТ) В ПЕДИАТРИИ}

\section{Hyperbare Sauerstofftherapie (HBOt) in Der Pädiatrie}

\section{TERAPIA DE OXIGENACIÓN HIPERBáRICa (TOHB) EN PEDIATRÍa}

\author{
Ernest Kuchar ${ }^{1)}$, Grzegorz Carowicz ${ }^{2}$ ) \\ 1) Paediatric Clinic with the Observation Department of the Medical University of Warsaw, Poland \\ ${ }^{1)}$ Klinika Pediatrii z Oddziałem Obserwacyjnym Warszawskiego Uniwersytetu Medycznego, Warszawa \\ 2) Open Pharmacy of Jelenia Góra; Pro-Farm Health Promotion Centre, Poland \\ ${ }^{2)}$ Apteka otwarta Jelenia Góra; Centrum Promocji Zdrowia Pro-Farm
}

\section{StREsZCZENIA / ABstRACTS}

Therapy with hyperbaric oxygen (HBOT) was first used in pediatrics in Russia in the 1920s (1927). At present, HBOT is used in children in similar indications as in adults, as well as in perinatal, neurologic and neuro-developmental conditions, even though there is only limited evidence of it offering any benefit for such conditions. The aim of this publication is to present current indications and risks of the use of HBOT in children.

Keywords: recomendations supportive treatment, alternative therapy, efficacy.

Terapia tlenem hiperbarycznym (HBOT), została po raz pierwszy zastosowana w pediatrii w Rosji w latach 30 XX wieku (1927 rok). Obecnie metoda HBOT jest u dzieci stosowana we wskazaniach zbliżonych jak u osób dorosłych, ponadto w zaburzeniach okołoporodowych, neurologicznych i neurorozwojowych, gdzie jej przydatność jest niezadawalająca. Celem artykułu jest przedstawienie aktualnych wskazań i ryzyka stosowania HBOT u dzieci.

Słowa kluczowe: zalecenia, leczenie wspomagające, terapia alternatywna, skuteczność.

Терапия гипербарической оксигенацией (НВОТ) была впервые применена в педиатрии в России в 30 -ые XX века (1927 года). Сегодня метод НВОТ применяется у детей при показаниях, приближенных к показаниях взрослых, а также при родовых травмах, неврологических нарушениях где ее эффективность является недостаточной. Целью статьи является представление актуальных показаний и степени риска применения НВОТ у детей.

Ключевые слова: рекомендации, поддерживающее лечение, альтернативное лечение, эффективность.

Die hyperbare Sauerstofftherapie (HBOT) wurde in der Pädiatrie erstmals in den 1930er Jahren (1927) in Russland angewendet. Gegenwärtig wird die HBO-Methode bei Kindern in ähnlichen Indikationen wie bei Erwachsenen angewendet, außerdem bei perinatalen, neurologischen und neurologischen Entwicklungsstörungen, wo ihre Nützlichkeit allerdings nicht zufriedenstellend ist. Ziel des Artikels ist es, aktuelle Indikationen und das Risiko der HBOTAnwendung bei Kindern darzustellen.

Schlüsselwörter: Empfehlungen, unterstützende Pflege, alternative Therapie, Wirksamkeit.

La terapia de oxigenación hiperbárica (TOHB) fue utilizada por primera vez en pediatría en Rusia en la década de los años 30 del siglo XX (1927). En la actualidad, el método TOHB se utiliza en niños para indicaciones similares a las de los adultos, así como para trastornos perinatales, neurológicos y del desarrollo neurológico, donde su utilidad es poco satisfactoria. El objetivo de este trabajo es presentar las actuales indicaciones y los riesgos del uso de TOHB en niños.

Palabras clave: recomendaciones, tratamiento de apoyo, terapia alternativa, eficacia.

ARTICLE INFO

PolHypRes 201 Vol. 62 Issue 1 pp. 55 - 60

ISSN: $1734-7009$ elSSN: $2084-0535$

DOI: $10.2478 /$ phr-2018-0004

Pages: 6, figures: 0 , tables: 0

page www of the periodical: www.phr.net.pl

Publisher

Polish Hyperbaric Medicine and Technology Society
Typ artykułu: przeglądowy

Rewiev article

Termin nadesłania: 14.01.2018 $\mathrm{r}$.

Termin zatwierdzenia do druku: $27.02 .2018 \mathrm{r}$. 


\section{WSTEP}

Wpływ tlenu hiperbarycznego na narządy i tkanki jest wielokierunkowy. W warunkach wysokich stężeń parcjalnych tlen staje się lekiem wywołującym wiele istotnych zjawisk w organizmie chorego dziecka, z których najistotniejszym jest wpływ na metabolizm komórek. Zastosowanie tlenu hiperbarycznego powoduje zwiększenie aktywności przeciwbakteryjnej leukocytów, zmniejsza adhezję neutrofili do ścian naczyń, tym samym ograniczając uszkodzenia śródbłonka, powoduje skurcz naczyń w obszarach o prawidłowym stężeniu tlenu, bez zmian w krążeniu w obszarach o upośledzonym przepływie, przywraca wzrost fibroblastów i produkcję kolagenu, stymuluje wytwarzanie dysmutazy nadtlenkowej i magazynowanie ATP, co sprzyja zmniejszeniu obrzęków tkanek, ogranicza niektóre mechanizmy odpowiedzi immunologicznej, pobudza aktywność osteoklastów, proliferację włośniczek, obniża elastyczność soczewek w oku, hamuje wytwarzanie surfaktantu w płucach, blokuje peroksydację lipidów przy zatruciu CO, jak też przyspiesza jego usuwanie $\mathrm{z}$ hemoglobiny tlenkowęglowej [11].

Tlen może być dostarczany dziecku zarówno poprzez umieszczenie go $\mathrm{w}$ atmosferze czystego tlenu, jak i poprzez zastosowanie masek i kapturów tlenowych $\mathrm{w}$ komorach, gdzie pacjenci przebywają $\mathrm{w}$ atmosferze powietrza. Obydwa wymienione sposoby zwiększają ciśnienie parcjalne tlenu $\mathrm{w}$ płucach oraz znacznie zwiększają jego stężenia w osoczu, głównie na zasadzie fizycznego rozpuszczania się tlenu w wodzie stanowiącej główny jego składnik. Pod ciśnieniem stosowanym w HBOT tlen rozpuszcza się w wodzie w ilościach do 20 razy większych niż w warunkach normo barycznych przy zwykłym, 21\% stężeniu tlenu w powietrzu. Zwiększenie stężenia tlenu w osoczu przyczynia się to do znacznego zwiększenia promienia dyfuzji tlenu $\mathrm{z}$ naczyń włosowatych do otaczających je tkanek. Przy ciśnieniu 3 ATA i oddychaniu 100\% tlenem jego prężność w osoczu może wynieść nawet $2000 \mathrm{~mm} \mathrm{Hg}$, co zwiększa dyfuzję tlenu do tkanek około czterokrotnie po stronie tętniczej, a dwukrotnie po stronie żylnej krążenia włośniczkowego. W pediatrii zwykle stosuje się HBOT w zakresie ciśnień do 2 ATM $[7,9]$.

Pierwsze doświadczenia $\mathrm{z}$ zastosowaniem terapii tlenem hiperbarycznym (HBOT) u dzieci przeprowadzono w Rosji, w trakcie resustytacji oddechowo-krążeniowej, w stanach uszkodzenia mózgu, a także w chorobie hemolitycznej noworodków. Początkowo do zabiegów HBOT kwalifikowano dzieci w ciężkim stanie ogólnym, u których wyczerpano pozostałe, dostępne wówczas możliwości terapeutyczne. Wykazano, że w zamartwicy noworodków, zastosowanie HBOT do trzech godzin po urodzeniu dziecka, u 3/4 dzieci poddawanych terapii, prowadziło do uratowania życia dziecka i późniejszego wyzdrowienia.

Zaobserwowano ponadto, że HBOT zmniejszała stężenie wolnej bilirubiny we krwi, zapobiegajac tym samym uszkodzeniu mózgu związanemu z żółtaczką jąder podstawy. Z czasem terapia tlenem hiperbarycznym znalazła zastosowanie jako leczenie wspomagające w licznych schorzeniach wieku dziecięcego. Specyfiką pediatrii są problemy zdrowotne związane z zaburzeniami rozwoju, wadami wrodzonymi i urazem okołoporodowym. HBOT bada się pod kątem przydatności

\section{INTRODUCTION}

The influence of hyperbaric oxygen on bodily organs and tissues is multidirectional. In the conditions of high partial concentrations, oxygen becomes a drug inducing numerous significant phenomena in the body of a sick child, the most important of which is the effect on cellular metabolism. The use of hyperbaric oxygen is known to: increase the antimicrobial activity of leukocytes; reduces the adhesion of neutrophils to the vascular walls thereby limiting endothelial damage; leads to vasocontriction in areas with a regular oxygen concentration without causing changes in circulation in the areas with an impaired flow; restores fibroblast growth and collagen production; stimulates generation of peroxide dismutase and ATP storage which reduces tissue oedema; limits some mechanisms of immunoogical response; stimulates osteoclast activity; promotes capillary proliferation; reduces the elasticity of the lens in the eye; inhibits the production of surfactant in the lungs; blocks lipid peroxidation during $\mathrm{CO}$ poisoning as well as accelerates the disposal of carbon monoxide [11].

Oxygen can be provided both by placing a child in an atmosphere of pure oxygen, and by using oxygen masks and hoods in the chambers where patients are kept in an air atmosphere. Both of these methods increase the partial pressure of oxygen in the lungs and significantly increase its concentrations in the plasma, mainly based on the principle of physical dissolution of oxygen in water which constitutes its main component. At the pressure used in HBOT, oxygen dissolves in water in quantities of up to 20 times higher than those encountered in normobaric conditions where oxygen concentrations of $21 \%$ are found. Increasing the oxygen concentration in plasma contributes to a significant increase in the oxygen diffusion radius from the capillaries to the surrounding tissues. While breathing with $100 \%$ oxygen at the pressure of 3 ATA, its pressure in the plasma can be as high as $2000 \mathrm{~mm} \mathrm{Hg}$, which increases the diffusion of oxygen to tissues on the arterial side by approximately four times and twice on the venous side of the capillary circulation. The HBOT pressure range applied in paediatric patients usually amounts to 2 ATM.

The first experiments using hyperbaric oxygen therapy (HBOT) in children were carried out in Russia, during respiratory-circulatory resuscitation, in states of brain damage, as well as in haemolytic disease in newborns. Initially, those children in a severe general condition were qualified for HBOT procedures for whom the remaining therapeutic options available at that time were exhausted. It was shown that in neonatal asphyxia, the application of HBOT up to three hours after the birth, led to saving the lives and subsequent recovery of $3 / 4$ of children subjected to this therapy.

It was also observed that HBOT reduced the concentration of free bilirubin in the blood, thus preventing brain damage associated with kernicterus. Over time, hyperbaric oxygen therapy has been used as supportive therapy in numerous childhood diseases. The specificity of paediatrics are health problems related to developmental disorders, congenital malformations and perinatal trauma. HBOT is tested for paediatric usefulness primarily in relation to neurological consequences of the said abnormalities. The greatest interest is instigated by the use of HBOT in cognitive disorders and paralysis, thus 
w pediatrii przede wszystkim $\mathrm{w}$ następstwach neurologicznych wspomnianych zaburzeń.

Największe zainteresowanie wzbudza zastosowanie HBOT w zaburzeniach poznawczych i porażeniach, wzbudzając nadzieję że, w połączeniu $\mathrm{z}$ rehabilitacją pomoże złagodzić objawy spastyczne, poprawić wzrok, słuch, mowę i pozostałe funkcje umysłowe $[4,5]$. W praktyce, podobnie jak u dorosłych, HBOT jest głównie stosowana u dzieci z niedokrwieniem lub niedotlenieniem tkanek i/lub trudno gojącymi się ranami, w celu wspomagania ich gojenia się równolegle ze stosowaną w tym samym czasie standardową terapią. Jednoczesne zastosowanie chirurgicznego oczyszczania rany, antybiotykoterapii i HBOT umożliwia uzyskanie efektu synergii, co znacznie przyspiesza gojenie ran [8].

Wskazania do zastosowania HBO w Europie uaktualniono ostatnio $\mathrm{w}$ oparciu o metodologię EBM na $\mathrm{X}$ konferencji uzgodnieniowej ECHM (European Committee of Hyperbaric Medicine) w Lille w dniach 15-16 kwietnia 2016 roku (ECHM Consensus Conference) [6]. Siłę dowodów na korzystny wpływ HBOT podzielono na 4 poziomy: (poziom I - silne dowody korzystnego wpływu HBOT, poziom II - dowody korzystnego wpływu HBOT, poziom III - słabe dowody korzystnego wpływu HBOT, poziom IV - brak dowodów korzystnego wpływu HBOT).

$\mathrm{Na}$ podstawie oceny dostępnych dowodów komitet wydał na zasadzie konsensusu rekomendacje, których siła mogła przyjąć trzy poziomy (rekomendacja stopnia I - silna, rekomendacja stopnia II - umiarkowana oraz rekomendacja stopnia III - słaba, opcjonalna). Jednocześnie jakość dowodów oceniono zgodnie z systemem GRADE (A - wysoka jakość dowodów, B- umiarkowana jakość dowodów, C- niska jakość dowodów, D- bardzo niska jakość dowodów) [6].

Do zaakceptowanych wskazań do stosowania HBOT także u dzieci zaliczono:

\section{Rekomendacja stopnia I (silna)}

- zatrucie tlenkiem węgla CO (B),

- otwarte złamania $\mathrm{z}$ urazem zmiażdżeniowym (B),

- $\quad$ profilaktyka martwicy kości po usunięciu zęba u pacjenta poddanego napromieniowaniu,

- martwica po napromieniowaniu i owrzodzenia popromienne (żuchwa, odbytnica, pęcherz) (B),

- choroba dekompresyjna (C),

- $\quad$ zator gazowy (C),

- zakażenia wywołane przez beztlenowce lub florę mieszaną $\mathrm{z}$ udziałem beztlenowców, martwica tkanek miękkich, zwłaszcza gangrena gazowa ( $\mathrm{C}$ ),

- nagła głuchota (idiopatyczna głuchota neurosenso-ryczna w ciągu 2 tygodni, maksymalnie do 6 miesięcy po wystąpieniu) (B).

Rekomendacja stopnia II (umiarkowana):

- trudno gojące się rany: stopa cukrzycowa (B), owrzodzenia niedokrwienne (C),

- martwica głowy kości udowej (B),

- przeszczepy skóry i płaty skórne zagrożone martwicą (C),

- urazy zmiażdżeniowe bez złamania kości (C),

- oparzenia III stopnia $>20 \%$ powierzchni ciała (C),

- przewlekłe zapalenie kości i szpiku oporne na leczenie (C), raising hopes that, combined with rehabilitation, it will help relieve spastic symptoms, improve sight, hearing, speech and other mental functions [4,5]. In practice, as in adults, HBOT is mainly used in children with ischaemia or tissue hypoxia and / or difficult-to-heal wounds, in order to complement the traditional therapy and to help improve the outcome of that therapy. The simultaneous use of surgical debridement, antibiotic therapy and HBOT facilitates a synergy effect, which significantly accelerates wound healing [8].

Indications for the use of HBOT in Europe have recently been updated based on the EBM methodology at the 10th ECHM (European Committee of Hyperbaric Medicine) consensus conference in Lille on 15-16 April 2016 [6]. The strength of evidence of the beneficial effects of HBOT was divided into 4 levels: (level I - strong evidence of beneficial effect of HBOT, level II - evidence of beneficial effects of HBOT, level III - poor evidence of beneficial effects of HBOT, level IV - no evidence of beneficial effects of HBOT).

On the basis of assessment of the available evidence, the committee issued recommendations based on consensus, whose strength could take three grades (recommendation of grade I - strong, recommendation of grade II - moderate and recommendation of grade III poor, optional). At the same time, the quality of evidence was assessed according to the GRADE system (A - high quality of evidence, B - moderate quality of evidence, C low quality of evidence, D - very low quality of evidence) [6].

The approved indications for the use of HBOT in children include:

\section{Grade I recommendation (strong)}

- $\quad$ CO poisoning (B),

- open fractures with a crush injury (B),

- prophylaxis of osteonecrosis after tooth extraction in a patient undergoing irradiation,

- necrosis after irradiation and radiation ulcers (mandible, rectum, bladder) (B),

- decompression sickness (C),

- gas embolism (C),

- infections caused by anaerobe or mixed flora with anaerobic involvement, soft tissue necrosis, especially gas gangrene (C),

- sudden deafness (idiopathic neurosensory deafness within 2 weeks, up to a maximum of 6 months after the occurrence) (B).

Grade II recommendation (moderate)

- hard healing wounds: diabetic foot (B), ischaemic ulcers (C),

- necrosis of the femoral head (B),

- $\quad$ skin grafts and skin patches endangered with necrosis $(\mathrm{C})$,

- crush injuries without bone fractures (C),

- third degree burns - $20 \%$ of the body surface (C),

- chronic osteomyelitis resistant to treatment (C),

- ccclusion of the central retinal artery (C),

- pneumatosis cystoides intestinalis (C),

- osteoradionecrosis of bones, excluding the mandible (C),

- radiation enteritis/proctitis (C),

- radiation-induced damage to soft tissues, excluding the rectum and bladder (C), 
- $\quad$ zator tętnicy środkowej siatkówki (C),

- pneumatosis cystoides intestinalis $(\mathrm{C})$,

- osteoradionekroza kości poza żuchwą (C),

- $\quad$ popromienne zapalenie jelit/odbytnicy (C);

- popromienne uszkodzenia tkanek miękkich, oprócz odbytnicy i pęcherza (C),

- zapobiegawczo w zabiegach chirurgicznych, w tym wszczepianiu implantów w napromieniowanych tkankach - (C),

- owrzodzenia niedokrwienne (C),

- $\quad$ neuroblastoma w stadium IV (C).

\section{Rekomendacja stopnia III (słaba)}

- urazy mózgu (ostre i przewlekłe urazy mózgu, przewlekły udar, encefalopatia po niedotlenieniu) (C),

- popromienne uszkodzenia OUN (C),

- popromienne uszkodzenie krtani lub ośrodkowego układu nerwowego (C),

- reimplantacja kończyn (C),

- $\quad$ oparzenia $>20 \%$ całkowitej powierzchni ciała (C),

- $\quad$ ostre zaburzenia niedokrwienne oczu - (C),

- zespół reperfuzji po zabiegach naczyniowych (C),

- $\quad$ przełom w niedokrwistości sierpowatej (C),

- niegojące się owrzodzenia w niedokrwistości sierpowatej $(C)$,

- $\quad$ śródmiąższowe zapalenie pęcherza (C).

Ze względu na brak danych klinicznych nie wydano rekomendacji dotyczących stosowania HBOT w następujących schorzeniach:

- zapalenie śródpiersia po rozcięciu mostka (D),

- złośliwe zapalenie ucha środkowego (D),

- $\quad$ ostry zawał mięśnia sercowego (D),

- zwyrodnienie barwnikowe siatkówki (D),

- $\quad$ porażenie nerwu twarzowego (D).

Analiza wyżej wymienionych wskazań pod względem przydatności w pediatrii wskazuje, że HBOT może być we wszystkich przypadkach zastosowana u dzieci [8]. Różnice dotyczą natomiast epidemiologii schorzeń będących wskazaniem do HBOT - stany takie jak np. stopa cukrzycowa, ostry zawał mięśnia sercowego, zwyrodnienie barwnikowe siatkówki czy nagła głuchota, które często występują wśród dorosłych i stanowią jedno z częstszych wskazań do HBOT są rzadkością w populacji wieku rozwojowego. $\mathrm{Z}$ kolei domeną pediatrii są zaburzenia neurologiczne i neurorozwojowe, gdzie niestety, przydatno HBOT jest niewielka. Autorzy rekomendacji uznali, że są dowody na brak korzystnego działania HBOT w następujących stanach klinicznych dotyczących głównie dzieci [11]:

- Schorzenia ze spektrum autyzmu (silne zalecenie nie stosowania HBOT, dowody B);

- Mózgowe porażenie dziecięce (silne zalecenie nie stosowania HBOT, dowody B);

- Niewydolność łożyska (silne zalecenie nie stosowania HBOT, dowody B);

- Stwardnienie rozsiane (silne zalecenie nie stosowania HBOT, dowody B);

- Szumy uszne (silne zalecenie nie stosowania HBOT, dowody B);

- Ostra faza udaru mózgu (silne zalecenie nie stosowania HBOT, dowody B).

Pomimo oczekiwań rodziców i pediatrów,
- $\quad$ preventive in surgical procedures, including implants in irradiated tissues - (C),

- $\quad$ ischaemic ulcers (C),

- $\quad$ neuroblastoma grade IV (C).

Grade III recommendation (poor)

- injuries of the brain (acute and chronic brain injuries, chronic stroke, hypoxia encephalopathy) (C),

- $\quad$ post-radiation damage to the CNS (C),

- post-radiation damage to the larynx or central nervous system (C),

- reimplantation of the limbs (C),

- burns $>20 \%$ of total body surface (C),

- acute ischaemic eye disease - (C),

- reperfusion syndrome following vascular surgeries (C),

- a breakthrough in sickle-cell anaemia (C),

- non-healing ulcers in sickle-cell anaemia (C),

- $\quad$ interstitial cystitis (C).

Due to the lack of clinical data, recommendations regarding the use of HBOT in the following diseases were not issued:

- inflammation of the mediastinum after dissection of the sternum (D),

- malignant medial otitis (D),

- acute myocardial infarction (D),

- retinal pigment degeneration (D),

- $\quad$ palsy of the facial nerve (D).

An analysis of the above-mentioned indications in terms of paediatric usefulness indicates that HBOT can be used in children in all cases. The differences relate to the epidemiology of the diseases in which it is recommended to use HBOT - such conditions as diabetic foot, acute myocardial infarction, retinal pigment degeneration or sudden deafness, which are common among adults and constitute one of the most frequent indications for HBOT are rare in the developmental age population. In turn, the paediatric domain concentrates on neurological and neurodevelopmental disorders, where, unfortunately, the usefulness of HBOT is small. The authors of the recommendations took into consideration the fact that there is evidence for a lack of beneficial effects of HBOT in the following clinical conditions mainly concerning children:

- Conditions from the autism spectrum (strong recommendation not to use HBOT, evidence B);

- Cerebral palsy (strong recommendation not to use HBOT, evidence B);

- Placental insufficiency (strong recommendation not to use HBOT, evidence B);

- Multiple sclerosis (strong recommendation not to use HBOT, evidence B);

- Tinnitus (strong recommendation not to use HBOT, evidence B);

- Acute phase of stroke (strong recommendation not to use HBOT, evidence B).

Despite the expectations of parents and paediatricians, previous experience with the use of HBOT in the treatment of children with autism spectrum or cerebral palsy is negative and HBOT should not be recommended in these conditions. Autism or broader autism spectrum (ASDs - autism spectrum disorders) constitute a continuum of complex, congenital brain developmental disorders that manifest themselves in 
dotychczasowe doświadczenia ze stosowaniem HBOT w leczeniu dzieci ze spektrum autyzmu lub mózgowym porażeniem dziecięcym są negatywne i HBOT nie powinna być w tych stanach zalecana. Autyzm lub szerzej spektrum autystyczne (ASDs - autism spectrum disorders) stanowią kontinuum złożonych, wrodzonych zaburzeń rozwojowych mózgu, które objawiają się u dzieci trudnościami w komunikacji werbalnej i pozawerbalnej, zaburzonymi interakcjami społecznymi oraz powtarzającymi się ograniczonymi stereotypiami ruchu lub innych zachowań.

Co prawda istnieje wiele dowodów, że HBOT zmniejsza nasilenie procesu zapalnego w mózgu u dzieci chorych na autyzm i wpływa na stężenia neuromediatorów, jednak nie wykazano by HBOT przynosiło korzyści chorym. Analizując rekomendowane przez ECHM wskazania do HBOT trzeba zwrócić uwagę, że występuje podstawowa różnica między „dowodami z badań klinicznych na brak działania” dostępnymi np. $\mathrm{w}$ stosunku do pacjentów ze spektrum autyzmu, a brakiem dowodów na korzystne działanie, która sytuacja dotyczy wielu, jeśli nie większości potencjalnych wskazań do HBOT u dzieci [1]. W takiej sytuacji autorzy rekomendacji zalecają indywidualną analizę korzyści do ryzyka.

W sytuacji gdy zastosowanie HBOT nie wiąże się $\mathrm{z}$ istotnym ryzykiem dla dziecka, a potencjalnie może mu pomóc, należy zastosować HBOT. Z kolei w przypadku, gdy zastosowanie HBT wiązało by się $\mathrm{z}$ istotnym ryzykiem dla dziecka, a schorzenie nie zostało wymienione w przedstawionej powyżej liście wskazań, z terapii HBO należy zrezygnować, zgodnie $\mathrm{z}$ zasadą sformułowaną przez Hipokratesa że „skoro nie można pomóc, po pierwsze nie należy szkodzić".

Przykładem z zakresu schorzeń neurologicznych, występujących u dzieci, które można rozważyć jako wskazanie do HBOT są bóle migrenowe i klasterowe głowy, często występujące u nastolatków, objawy neurologiczne towarzyszące zespołom FAS czy ADHD i inne schorzenia i objawy ze strony układu nerwowego, w których brak dowodów na korzystne działanie HBOT, ale też nie ma dowodów na brak przydatności HBOT, szczególnie, gdy $\mathrm{w}$ badaniach czy opublikowanych doniesieniach zaobserwowano jakikolwiek korzystny wpływ lub istnieją teoretyczne przesłanki, że HBOT może okazać się korzystne [2].

Przykładowo w jednym $\mathrm{z}$ badań RCT stwierdzono korzystny wpływ HBOT na zespół FAS (Fetal Alcoholic Syndrome) w postaci poprawy czasu reakcji, lepszego skupiania uwagi oraz rozpoznawania obrazów, co budzi nadzieje, że HBOT może przynieść korzyść dzieciom. Podobnie w kilku badaniach dotyczących zastosowania HBOT u dzieci z zespołem ADHD uzyskano zachęcające wyniki w postaci: uspokojenia i wyciszenia, ograniczenia wahań nastoju, poprawy funkcji trawiennych i spokojniejszego snu [7].

\section{RYZYKO TERAPII HBOT U DZIECI}

Skutki uboczne HBOT wynikają z pojawienia się różnicy ciśnień pomiędzy poszczególnymi zamkniętymi przestrzeniami organizmu oraz toksyczności hiperbarycznego tlenu czyli tego samego mechanizmu, któremu HBOT zawdzięcza swoje działanie. Do głównych działań niepożądanych HBOT związanych z różnicą ciśnień możemy zaliczyć pęknęcie błony bębenkowej children with difficulties in verbal and non-verbal communication, disturbed social interactions and repeated limited stereotypes of movement or other behaviours.

It is true that there is much evidence that HBOT reduces the severity of encephalitis in children with autism and affects the concentration of neurotransmitters, however it has not been demonstrated that HBOT benefited the patients. When analysing the indications for HBOT recommended by ECHM, it should be noted that there is a fundamental difference between "evidence from clinical studies of a lack of effect" available e.g. in relation to patients with autism spectrum, and the lack of evidence for a favourable effect, which concerns many, if not the majority of potential indications for HBOT in children [1]. In this situation, the authors of the recommendations advise an individual risk-benefit analysis.

In situations where the use of HBOT does not involve a significant risk for a child and may potentially help, HBOT should be used. In turn, if the use of HBOT involves a significant risk for the child and the illness was not mentioned in the above list of indications, the HBO therapy should not be applied in concord with the principle formulated by Hippocrates "whenever a doctor cannot do good, he must be kept from doing harm."

An example of neurological disorders in children that may be considered as an indication for HBOT are migraine and cluster headaches often occurring in adolescents, neurological symptoms accompanying FAS or ADHD syndromes, and other nervous system disorders and symptoms in which there is no evidence for the beneficial effects of HBOT, however there also is no evidence of HBOT's lack of effectiveness, particularly when some beneficial effects have been observed in studies or published reports or when there are theoretical indications that HBOT may be beneficial [2].

For example, one of the RCT studies showed a beneficial effect of HBOT on FAS (Foetal Alcoholic Syndrome) in the form of an improved reaction time, better attention and image recognition, which raises hopes that HBOT can benefit children. Similarly, in several studies on the use of HBOT in children with ADHD, encouraging results were obtained in the form of its calming effect, reduction of mood swings, improvement of digestive functions and peaceful sleep [7].

\section{THE RISK OF HBOT THERAPY IN CHILDREN}

The side effects of HBOT result from an occurrence of a pressure difference between particular closed spaces of the body and the hyperbaric oxygen toxicity, i.e. the very mechanism to which HBOT owes its effect. The main side effects of HBOT associated with pressure differences include rupture of the eardrum and pneumothorax, whereas oxygen toxicity may lead to myopia and epileptic seizures.

To summarise the current knowledge about HBOT in children, it can be concluded that the therapy can be used in relation to all indications mentioned in ECHM recommendations, providing that a child, particularly a small one, is ensured comfortable conditions. This usually involves the presence of a carer in the hyperbaric chamber and requires the exclusion of contraindications on his/her part (qualification to undergo HBOT like 
i odmę opłucnową, natomiast następstwem toksyczności tlenu może być krótkowzroczność i napady padaczkowe.

Podsumowując aktualną wiedzę na temat HBOT u dzieci, można stwierdzić, że terapia może być stosowana we wszystkich wskazaniach wymienionych $\mathrm{w}$ rekomendacjach ECHM, pod warunkiem zapewnienia dziecku, zwłaszcza małemu, komfortowych warunków, co zwykle wiąże się z obecnością w komorze hiperbarycznej opiekuna i wymaga wykluczenia przeciwwskazań z jego strony (zakwalifikowanie do HBOT podobnie jak pacjenta) [16].

W częstych $\mathrm{w}$ pediatrii sytuacjach, gdy brakuje dowodów na korzystny wpływ HBOT, jednak występują przesłanki, które na możliwość takiego wpływu wskazują, wynikające czy to z badań na zwierzętach czy opisów przypadków lub serii przypadków, należy rozważyć zastosowanie HBOT indywidualnie oceniając ryzyko działań niepożądanych. Warunkiem zakwalifikowania to HBOT jest małe ryzyko szkodliwego wpływu HBOT. Niezbędne jest prowadzenie badań nad zastosowaniem HBOT u dzieci, które pozwolą ściślej określić wskazania i przeciwwskazania oraz usuną dzisiejsze wątpliwości lekarzy wynikłe z braku danych [15]. a regular patient) [16].

However, in frequent paediatric situations where there is a lack of evidence for the beneficial effect of HBOT based on animal studies, case reports or a series of cases, the use of HBOT should be considered by an individual assessment of the risk of side effects. The condition for qualifying for HBOT consists in a low risk of a harmful impact of HBOT. It is necessary to conduct research on the use of HBOT in children, which will enable a more precise definition of indications and contraindications and dispel today's doubts of physicians resulting from the lack of data [15].

\section{REFERENCES}

1. Ahmad Ghanizadeh Hyperbaric oxygen therapy for treatment of children with autism: a systematic review of randomized trials Med Gas Res. 2012; 2: 13. www.ncbi.nlm.nih.gov/pmc/articles/PMC3369206/; DOI: 10.1186/2045-9912-2-13

2. Daniel A Rossignol, James J Bradstreet, Kyle Van Dyke et al.;

3. Hyperbaric oxygen treatment in autism spectrum disorders Med Gas Res. 2012; 2: 16. www.ncbi.nlm.nih.gov/pmc/articles/PMC3472266/;

4. G. Nuthall, M. Seear, M. Lepawsky et al. Hyperbaric Oxygen Therapy for Cerebral Palsy: Two Complications of Treatment Pediatrics 2000, 106(6)

5. http://pediatrics.aappublications.org/content/106/6/e80.full; 6. Virginia Neubauer, Richard Neubauer and Paul Harch HBOT in the Management of Cerebral Palsy.
http://www.hbot.com/blog/infinitee/hyperbaric-oxygen-therapy-management-cerebral-palsy;

7. McMaster University CanChild Hyperbaric Oxygen Therapy (HBOT) as a 'treatment' for Cerebral Palsy https://www.canchild.ca/en/resources/212-hyperbaric-oxygen-therapy-hbot-as-a-treatment-for-cerebral-palsy;

8. Marek Kawecki, Grzegorz Knefel, Bożena Szymański, Mariusz Nowak Aleksander Sieroń: Current indications and possible applications of hyperbaric oxygen therapy;

9. Perrins ER, Bissonnette R. Frostbite, a new adjunct in treatment. JAMA 1965;194:211.7. Ward MP, Garnham JR. Frostbite: general observations and report of cases treated by hyperbaric oxygen. Proc Roy Soc Med

10. Gage AA, Ishikawa H. Experimental frostbite. The effect of hyperbaric oxygenation on tissue survival. Cryobiology 1970;7(1):1-8.;

11. Cooke JN. Hyperbaric oxygen treatment in the Royal Air Force. Proc Roy Soc Med 1971;64(9):881-2. 5 Hardenbergh E.;

12. Hyperbaric oxygen treatment of experimental frostbite in the mouse. J Surg Res 1972;12(1):34-40;

13. Thom SR. Hyperbaric oxygen: its mechanisms and efficacy. Plast Reconstr Surg 2011;127(suppl 1):13 1S-14 1S, $\square$ DOI: 10.1097/PRS.0b013e3181fbe2bf

14. Rihova J. Omrzliny - nikdy se nevzdavat. Med Sport Boh Slov 2005;14(1):21-25;

15. Jain KK: Textbook of hyperbaric medicine. Wyd. 4. Hogrefe \& Huber Publishers, Göttingen 2004.2. Mathieu D: Handbook on hyperbaric medicine. Springer, Dordecht 2006;

16. Mathieu D: Handbook on hyperbaric medicine. Springer, Dordecht 2006;

17. Sieroń A, Cieślar G, Kawecki M: An outline of hyperbaric medicine. a-Medica Press, Bielsko-Biała 2006;

18. Andrzej Zawadzki, Emergency and catastrophe medicine, PZWL, Warsaw 2011.

dr hab. n. med. Ernest Kuchar

Klinika Pediatrii z Oddziałem Obserwacyjnym

Warszawski Uniwersytet Medyczny

ul. Żwirki i Wigury 61 02-091 Warszawa

ernest.kuchar@gmail.com 